\title{
Isolation and Properties of a Phospholipid-hydrolysing Bacterium from Ovine Rumen Fluid
}

\author{
By G. P. HAZLEWOOD AND R. M. C. DAWSON \\ Department of Biochemistry, A.R.C. Institute of Animal Physiology, \\ Babraham, Cambridge CB2 $4 A T$
}

(Received I5 January 1975)

\begin{abstract}
SUMMARY
A bacterium which can rapidly degrade phospholipids has been isolated from the ovine rumen and tentatively identified as a non-cellulolytic strain of Butyrivibrio fibrisolvens. When the organism was grown in batch culture the phospholipase activity appeared during the late exponential phase, peaked 4 to $8 \mathrm{~h}$ after maximum culture turbidity had been reached, and then rapidly disappeared. Activity was associated both with the whole cells and the cell-free culture supernatant.

Phosphatidylcholine was degraded via lysolecithin to produce free fatty acids and glycerylphosphorylcholine, indicating phospholipase $A+B$ activity. The activity was stimulated by the addition to the incubation medium of oleic acid or sodium dodecylsulphate. There was no requirement for divalent cations, but the presence of cysteine at $1 \mathrm{O}^{-2} \mathrm{M}$ stimulated the activity many-fold even though the incubation was performed under an oxygen-free gas phase. Phosphatidylethanolamine and phosphatidylinositol were also attacked. The possible role of the organism in bringing about the degradation in the rumen of plant phospholipids in the sheep's diet is discussed.
\end{abstract}

\section{INTRODUCTION}

Early studies showed that ovine rumen contents rapidly hydrolysed a ${ }^{32} \mathrm{P}$-labelled lecithin substrate added in the pure liquid crystalline form (Dawson, 1959). The degradative pathway was primarily, but not exclusively, through a deacylation producing initially glycerylphosphorylcholine which was subsequently decomposed to glycerophosphoric acid and choline. More recently the rapid decomposition of lecithin in plant materials fed to sheep without ciliated protozoa in their rumen has been demonstrated (Dawson \& Kemp, 1969a), as well as the catabolism of lecithin in totally-labelled ${ }^{14} \mathrm{C}$-grass introduced into the normal rumen (Dawson \& Hemington, 1974a).

It is possible that a certain proportion of dietary plant lipids may be decomposed in the rumen by lipolytic enzymes present in the leaves themselves, rather than by micro-organisms (Dawson \& Hemington, I974a; Faruque, Jarvis \& Hawke, 1974). However, the pathway of lecithin degradation which was observed to proceed via glycerylphosphorylcholine does not fit in with the action of the main phospholipid-hydrolysing enzyme found in leaves, phospholipase $\mathrm{D}$. In addition, ruminant saliva contains a powerful inhibitor of plant phospholipase D (Dawson \& Hemington, 1974b) so that little activity is present in the bolus delivered to the rumen.

We have, therefore, investigated the ability of individual rumen bacteria to hydrolyse exogenous phospholipids to see if such an activity is a widespread property of many different species of bacteria or is confined to certain organisms. This has resulted in the isolation of 
a Butyrivibrio sp. which is especially active in completely deacylating diacyl phosphoglycerides. The characteristics of the organism and the properties of the enzyme are described.

\section{METHODS}

Animals. Clun-Forest sheep were rumen-fistulated by Dr P. Kemp and maintained on hay-chaff ( $800 \mathrm{~g})$ and crushed oats $(200 \mathrm{~g})$ fed once daily, or on pasture. Rumen contents were removed by aspiration and strained through muslin to remove coarse food particles. Sheep with defaunated rumens were prepared by adapting the method of Abou Akkada et al. (1968) to sheep (Dawson \& Kemp, I969a).

Labelled substrates. ${ }^{32}$ P-labelled phosphatidylcholine, phosphatidylethanolamine and phosphatidylinositol were prepared biosynthetically using Saccharomyces cerevisiae (Bangham \& Dawson, I960; Hauser \& Dawson, 1967). The phospholipids were initially separated on alumina columns as described, the phosphatidylcholine being removed with chloroformmethanol $(\mathrm{I}: \mathrm{I}, \mathrm{v} / \mathrm{v})$ and phosphatidylethanolamine plus phosphatidylinositol with chloroform-ethanol-water ( $2: 5: 2$, by vol.). The former phospholipid was purified by silicic acid column chromatography, the latter two were separated and purified by preparative t.l.c. using two solvent systems (Coleman, Kemp \& Dawson, 1971). They were located by autoradiography after each run.

Phospholipase assay. Phospholipase activity was assayed by incubating ${ }^{32} \mathrm{P}$-phospholipid at $39{ }^{\circ} \mathrm{C}$ and under oxygen-free $\mathrm{CO}_{2}$ with the appropriate bacterial suspension, together with added cofactors, in a total volume of $5 \mathrm{ml}$. The yeast phospholipid suspension was obtained by drying down suitable samples of ${ }^{32} \mathrm{P}$-phospholipid and non-radioactive yeast phospholipid from chloroform solution, and shaking the residue with buffer and a single glass bead in a vortex mixer. It was added to give a final concentration of 5 to $12 \mu \mathrm{g} \mathrm{P} / \mathrm{ml}$. The lecithin suspension was sometimes ultrasonicated for $10 \mathrm{~min}$ in a $\mathrm{KB} 80 / 1$ ultrasonic bath (Kerry, Basildon, Essex) before being added to the incubation medium. The incubation was terminated by adding $80 \mathrm{ml}$ chloroform-methanol $(2: \mathrm{r}, \mathrm{v} / \mathrm{v})$, and after standing for 30 min the single-phase mixture was shaken with 0.2 vol. water. On centrifuging, a lower, chloroform-rich phase separated, containing unchanged substrate, fatty acids and lysolecithin, while the upper aqueous phase contained any ${ }^{32} \mathrm{P}$ water-soluble decomposition products. Radioactivity in the upper and lower phases was determined by evaporating Io $\mathrm{ml}$ portions to dryness and oxidizing the residues with $\mathrm{I} \cdot 2 \mathrm{ml}$ perchloric acid $(72 \%, \mathrm{w} / \mathrm{v})$ on a shielded digestion rack. After the addition of $8.3 \mathrm{ml}$ water to each digested sample the Cerenkov radiation emitted (Lanchli, 1969) was monitored on a Nuclear Chicago liquid scintillation counter (Unilux II).

Determinations of the nature and quantity of the reaction products. Phosphate esters liberated when various phospholipid substrates were incubated with bacterial suspensions were examined in the upper aqueous phase $(0.5$ to $1.5 \mathrm{ml})$ prepared as above by paper ionophoresis and chromatography (Dawson, 1956; Sheltawy \& Dawson, 1969). Lipid hydrolysis products were detected using thin-layer chromatography on Kieselgel $F_{254}$ plates (Merck). The plates were first run in diethylether to remove pigments and apolar lipids to the solvent front and then in chloroform-methanol- $\mathrm{NH}_{3}$ (sp. gr. 0.880)- $\mathrm{H}_{2} \mathrm{O}$ (I I0:50:3:5, by vol.) to separate the phospholipids. Phosphorus-containing lipids were detected by autoradiography or the spray reagent of Vaskovsky \& Kostetsky (1968).

${ }^{32} \mathrm{P}$-radioactivity was determined by carefully digesting either the cut-out paper spots or the scraped-off silica gel spots with perchloric acid $(\mathrm{I} \cdot 2 \mathrm{ml})$. The digest was diluted to $9 \cdot 3 \mathrm{ml}$ with water and counted by Cerenkov radiation in a Nuclear Chicago liquid scintillation 
counter (Unilux II). A portion of this solution was then removed for micro-determination of phosphorus as described by Bartlett (1959).

Isolation of bacteria from rumen fluid. Isolations were achieved by the use of highlyreduced media capable of supporting the growth of obligately-anaerobic, rumen bacteria. The preparation, distribution, inoculation and incubation of such media were all carried out by the open-tube technique under an atmosphere of sterile oxygen-free carbon dioxide (Hungate, 1969; Latham \& Sharpe, 1971). Although a number of different media and techniques were used in an attempt to isolate organisms possessing considerable phospholipase activity, the most active bacterial isolates were obtained using the selective medium described by Hobson \& Mann (197I). This medium contained emulsified linseed oil droplets as the only energy source. Rumen fluid was removed from a pasture-fed sheep and centrifuged at $17400 \mathrm{~g}$ for $20 \mathrm{~min}$ to remove large micro-organisms. The supernatant containing the smaller bacteria, which initial experiments had shown to be a rich source of phospholipase activity, was diluted serially using the complete medium minus linseed oil as diluting fluid. Portions $(0.5 \mathrm{ml})$ of each dilution were used to inoculate roll bottles containing $5 \mathrm{ml}$ of medium prepared as described by Hobson \& Mann (I97I). After incubation at $30^{\circ} \mathrm{C}$, colonies were picked from the medium in the manner described by Hungate (1969) and Latham \& Sharpe (I97I) and inoculated into broths of the above medium and a nonselective medium containing rumen fluid and a number of different carbon sources (medium 2; Hobson, 1969). Phospholipase activity of the isolates was scanned by growing them in the non-selective medium containing a portion of sonicated ${ }^{32} \mathrm{P}$-yeast lecithin (prepared as above) at a final concentration of $5 \mu \mathrm{g} \mathrm{P} / \mathrm{ml}$ broth. After a period of incubation well in excess of that required to produce maximum turbidity, the tubes were assessed for lecithin breakdown as described under Phospholipase assay. Isolates possessing phospholipase activity were maintained on slopes of the non-selective medium containing agar $(2 \%, \mathrm{w} / \mathrm{v})$ and $0.5 \%(\mathrm{w} / \mathrm{v})$ glucose. The inoculated slopes were incubated for $48 \mathrm{~h}$ at $39^{\circ} \mathrm{C}$ and then stored at $3{ }^{\circ} \mathrm{C}$ for 4 weeks, when they were again subcultured. The purity of isolates was checked by examining gross morphology of successive subcultures by Gram-stained smears. Contaminated cultures were purified by rediluting them in roll tubes and picking single colonies for culture in broth.

On the basis of these tests, a Gram-negative rod designated LM8/ I B was selected for further examination since it consistently hydrolysed 80 to $100 \%$ of a lecithin substrate under the test conditions.

Culture conditions used for examining phospholipase activity. The organism LM8/IB was grown in non-selective liquid medium 2 (Hobson, 1969) modified so that the rumen fluid was replaced by a mixture of volatile fatty acids and haemin at levels which, according to Caldwell \& Bryant (1966), simulated the concentration of these substances in a medium containing $20 \%(\mathrm{v} / \mathrm{v})$ rumen fluid. The fermentable sugar was glucose $(0.5 \%, \mathrm{w} / \mathrm{v})$; the required low redox potential was achieved by including $0 . \mathrm{I} \%(\mathrm{w} / \mathrm{v})$ cysteine- $\mathrm{HCl}$ and the buffering capacity was increased by adding I \% (w/v) $\mathrm{NaHCO}_{3}$. The medium $(200 \mathrm{ml})$ was prepared in $250 \mathrm{ml}$ Erlenmeyer flasks with optically-matched side arms, and inoculated from a culture which had been grown to maximum turbidity and stored at $3{ }^{\circ} \mathrm{C}$ for $3 \mathrm{~h}$ before use. The flask was incubated at $39^{\circ} \mathrm{C}$ in an orbital incubator (Gallenkamp Ltd). Growth was measured by tipping some of the bacterial suspension into the side arm and assessing the turbidity in an EEL portable colorimeter (Evans Electroselenium Ltd), at $530 \mathrm{~nm}$. Standard curves relating the turbidity of liquid cultures of the organism LM8/IB to bacterial $\mathrm{N}$ and dry weight were linear over the ranges $\circ$ to $0.12 \mathrm{mg} \mathrm{N} / \mathrm{ml}$ and 0 to $\mathrm{I} \cdot 0 \mathrm{mg}$ dry weight $/ \mathrm{ml}$, respectively. Portions $(5 \mathrm{ml})$ of the bacterial suspension were removed 
aseptically, centrifuged at $2000 \mathrm{~g}$ for $10 \mathrm{~min}$ and the supernatant removed and stored under $\mathrm{CO}_{2}$. The bacteria were washed by suspending in cysteine-containing buffer and centrifuging, and then resuspended in $5 \mathrm{ml}$ of the same buffer for incubation with the phospholipid substrate (see above).

Identification of isolated bacterium. The biochemical tests employed for identification purposes were based on those described by Hobson (1969) with the basal medium 2 being varied in composition according to the requirements of each test. Single carbohydrates $(0.2 \%, w / v)$ or $\operatorname{starch}(0.5 \%, w / v)$ were added to the medium without agar. Cellulose digestion tests were carried out according to the two procedures described by Hobson \& Mann (1971). Volatile fatty acid production was measured in medium 2 devoid of agar, rumen fluid and all carbohydrates except glucose $(0.5 \%, \mathrm{w} / \mathrm{v})$. Volatile fatty acid utilization was measured in the same medium to which rumen fluid had been added. Volatile fatty acids were analysed by g.1.c. after growth for $48 \mathrm{~h}$ at $39{ }^{\circ} \mathrm{C}$. A portion of the culture medium was mixed with $20 \%(\mathrm{v} / \mathrm{v})$ of $6 \mathrm{M}-\mathrm{HCl}$ and $5 \mu \mathrm{l}$ applied to a column of $20 \%$ (w/w) Tween 80 coated on 100 to 120 mesh Gas-chrom Z (Applied Science Laboratories). Separation was carried out at $140^{\circ} \mathrm{C}$ with argon as carrier gas ( 30 to $40 \mathrm{ml} / \mathrm{min}$ ) in a Pye Unicam series I04 chromatograph with a flame ionization detector. Ethanol and hydrogen production were measured in the complete medium 2 minus agar after growth of the organism at $39^{\circ} \mathrm{C}$ for $24 \mathrm{~h}$. Ethanol was determined by g.l.c. as above, except that a column of Chromosorb 102 (Phase Separations Ltd) was used and a temperature of $145^{\circ} \mathrm{C}$. A sample of the gas phase was injected into a Pye Unicam series 104 chromatograph fitted with a Katharometer head. The column packing used was molecular sieve (MS 5 A; Pye Unicam Ltd), with $\mathrm{N}_{2}$ at a flow rate of $40 \mathrm{ml} / \mathrm{min}$ as the carrier gas and $18^{\circ} \mathrm{C}$ as the operating temperature. On such columns, $\mathrm{H}_{2}, \mathrm{CH}_{4}$ and $\mathrm{O}_{2}$ are readily separated although $\mathrm{CO}_{2}$ is irreversibly absorbed.

\section{RESULTS}

In initial experiments it became apparent that the phospholipase activity present in consecutive, similar batch cultures of the organism LM8/IB was extremely variable. Eventually it was found that to obtain more or less reproducible levels of activity, it was necessary to assay the enzyme at a specific stage of growth and also to supplement the incubation medium with an activator such as free fatty acid or sodium dodecylsulphate. In addition, all attempts to store the active washed bacteria or culture supernatant at low temperatures or with enzyme stabilizers such as glycerol failed to prevent a rapid fall-off in enzymic activity, which meant that for each enzyme experiment it was necessary to grow the organism and use the culture immediately.

\section{Relationship between growth phase and activity}

Figure I shows a typical development of the enzymic activity responsible for phosphatidylcholine degradation. Such results, which were reproduced in essential detail in a number of similar experiments, showed that the enzymic activity became apparent only during the late exponential phase of growth. It appeared to rise towards a maximum about 4 to $8 \mathrm{~h}$ after the maximum culture turbidity had been reached, by which time the turbidity and the bacterial nitrogen $/ \mathrm{ml}$ of culture were decreasing, indicating that autolysis was probably occurring. Additional confirmation of this was obtained by electron microscopy, which showed that $4 \mathrm{~h}$ after maximum culture turbidity 10\% of the cells were degenerating or were already disrupted. Enzymic activity decreased to almost negligible levels within $20 \mathrm{~h}$ of the culture reaching its maximum turbidity. The greater part of the activity was associated 


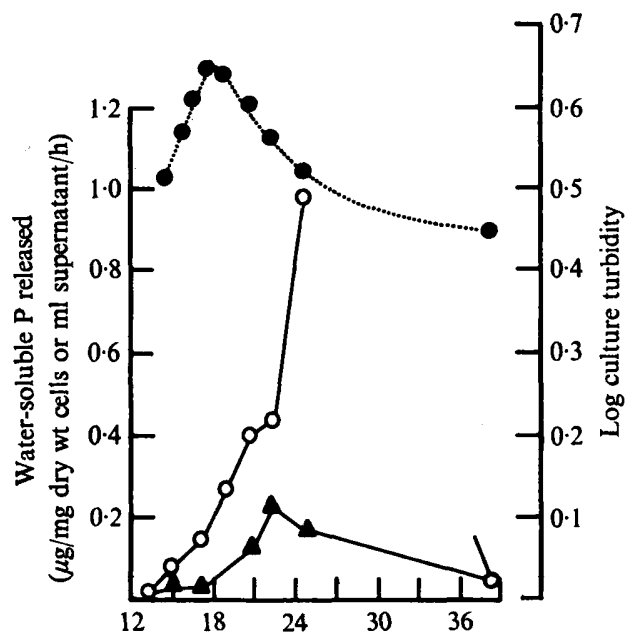

(a)

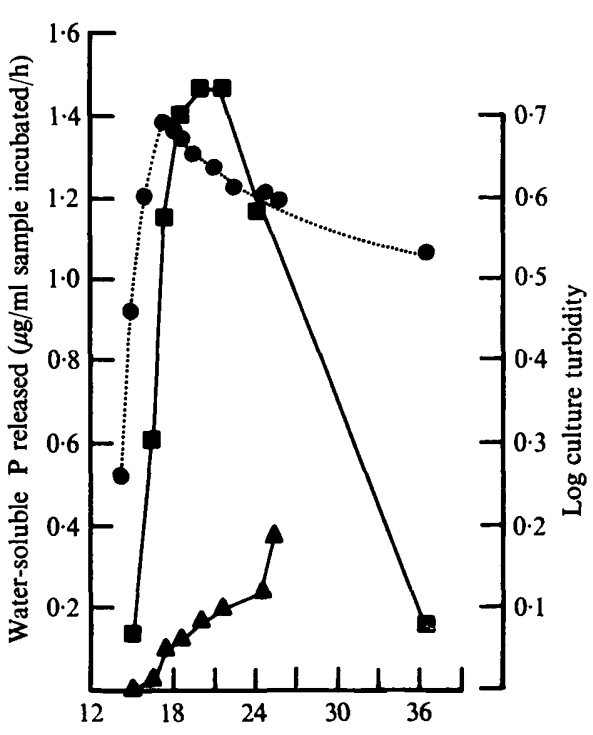

(b)

Fig. I. Relationship between growth phase and phospholipase activity for a shake-flask culture. $(a)$ and $(b)$ show the results of two typical experiments. Cells from $5 \mathrm{ml}$ portions of culture were harvested by centrifuging at $2000 \mathrm{~g}$ for $10 \mathrm{~min}$ at various stages during the growth of a shake-flask culture of $\mathrm{LM} 8 / \mathrm{IB}$, and were washed once with $0 \cdot 1 \mathrm{M}-\mathrm{NaOH}$-dimethylglutaric acid buffer $\mathrm{pH} 6 \cdot 8$ containing cysteine $\left(\mathrm{IO}^{-2} \mathrm{M}\right)$ and EDTA $\left(\mathrm{IO}^{-3} \mathrm{M}\right)$, before being resuspended to $4 \mathrm{ml}$ volume in the same buffer. After equilibration at $39^{\circ} \mathrm{C}$ under a $\mathrm{CO}_{2}$ gas phase, the cells were transferred to tubes containing yeast [ ${ }^{32} \mathrm{P}$ ]phosphatidylcholine $(2 \mu \mathrm{mol})$, potassium oleate $(2 \mu \mathrm{mol})$ and a glass bead. Each tube was gassed with $\mathrm{O}_{2}$-free $\mathrm{CO}_{2}$, vortexed for $30 \mathrm{~s}$ to disperse the substrate and incubated at $39^{\circ} \mathrm{C}$ for $2.5 \mathrm{~h}$. Phospholipase activity of: $\square$, whole culture; $\bigcirc$, washed cells; $\Delta$, cell-free culture supernatant;, turbidity.

with the whole bacteria but there was always a small, but variable, amount of activity found in the supernatant. This latter activity could not be sedimented by centrifugation ( 30 min at $96000 \mathrm{~g}$ ) so it would appear to be truly soluble and not associated with distinct fragments of bacterial membrane. Many attempts were made to liberate soluble enzyme from late exponential phase cells but none of these were successful. The methods tried included ultrasonic disruption, passage through a French pressure cell, and the lysis of both growing and autolysing cells, either by suspension in a suitable buffer and re-incubation at the growth temperature or by the addition of butanol (Hayaishi \& Kornberg, 1954) followed by reincubation. As a result of the instability of the enzyme and the difficulty in solubilizing the bulk of the activity from the bacteria, subsequent experiments were confined to washed cells harvested from cultures $4 \mathrm{~h}$ after the attainment of maximum turbidity and these were incubated with substrate as quickly as possible (up to 20 min after washing).

\section{Nature of the enzymic products formed from phosphatidylcholine}

The major water-soluble ${ }^{32} \mathrm{P}$-labelled product formed by the breakdown of ${ }^{32} \mathrm{P}$-phosphatidylcholine co-chromatographed on paper with a glycerylphosphorylcholine standard in two solvent systems: phenol saturated with water-acetic acid-ethanol (100:10: 12, by vol.), $\boldsymbol{R}_{F} 0.93$, and ethanol-ammonia (sp. gr. 0.880) $-\mathrm{H}_{2} \mathrm{O}\left(7: 3: \mathrm{I}\right.$, by vol.), $\boldsymbol{R}_{F} 0.54$. No phosphorylcholine or glycerophosphoric acid could be detected, although a small percentage of the total water-soluble radioactivity was present as inorganic P. Lipid-soluble ${ }^{32}$ P-radio- 
activity examined by t.l.c. resided chiefly in unchanged phosphatidylcholine $\left(R_{F} 0 \cdot 22\right)$, although a small proportion of a slower moving spot $\left(R_{F} 0 \cdot 06\right)$, co-chromatographing with a lysolecithin marker, was always present.

\section{Breakdown of phosphatidylethanolamine and phosphatidylinositol}

Both ${ }^{32}$ P-labelled phosphatidylethanolamine and phosphatidylinositol were broken down to water-soluble products when incubated with the washed, whole-cell fraction from a stationary-phase batch culture. The breakdown of phosphatidylethanolamine was never complete; for example, in a typical experiment with $10 \mu \mathrm{g}$ phosphatidylethanolamine $\mathrm{P} / \mathrm{ml}$ and $0.57 \mathrm{mg}$ dry wt cells $/ \mathrm{ml}, 20 \%$ of the lipid $\mathrm{P}$ had been rendered water-soluble after $\mathrm{I} \mathrm{h}$ and this had only increased to $26 \%$ after $3 \mathrm{~h}$. Somewhat more substantial breakdown $(75 \%$ in $\mathrm{I} h$ ) was obtained in incubations in which the cell to phospholipid concentration ratio was increased threefold. Paper chromatography of the water-soluble ${ }^{32} \mathrm{P}$-products in phenol saturated with $\mathrm{H}_{2} \mathrm{O}$-ethanol-acetic acid (100:12:10, by vol.) showed that initially the major water-soluble product was ninhydrin-reacting and co-chromatographed with a glycerylphosphorylethanolamine standard $\left(R_{F} 0.64\right)$. Subsequently glycerophosphoric acid $\left(R_{F} 0.29\right)$ and inorganic phosphate $\left(R_{F} 0.14\right)$ appeared in the fraction, indicating that liberated glycerylphosphorylethanolamine was being further hydrolysed by the actions of phosphodiesterase and phosphomonoesterase. In occasional incubations, there also appeared a minor water-soluble ${ }^{32} \mathrm{P}$-spot in the region of phosphorylethanolamine. The mechanism of its formation is unknown, although phosphorylethanolamine has been identified as a minor product in the degradation of phosphatidylethanolamine by a rumen ciliate protozoon, Entodinium caudatum (Coleman et al. 197I). Thin-layer chromatography of the lipid fraction obtained after incubation with the present organism indicated that although lysophosphatidylethanolamine had been formed there were also a variety of $\mathrm{N}$-acylated products formed by transacylation.

In further experiments [32P]phosphatidylinositol was incubated with LM8/I B cells for $4 \mathrm{~h}$. Only $8 \%$ of the substrate was broken down into water-soluble ${ }^{32} \mathrm{P}$, and the product appeared to be entirely inorganic phosphate. No lipid component apart from the original substrate could be detected in the chloroform-soluble fraction.

\section{Stimulating effect of fatty acid and sodium dodecylsulphate on enzymic activity}

Because of the reported activation of phospholipase A from various sources by fatty acid (Epstein \& Shapiro, 1959; Subbaiah \& Ganguly, 1970; Waite et al. 1969) and sodium dodecylsulphate (Bangham \& Dawson, 1959; Dawson \& Hauser, 1967), these substances were tested in the present system. The addition of potassium oleate to the incubation medium produced a 7- to ro-fold stimulation of lecithin breakdown. The liberation of both lysolecithin and glycerylphosphorylcholine reached maximum values when the oleate was added in approximately equal molar amount to that of the substrate: higher ratios caused inhibition (Fig. 2). The breakdown of phosphatidylinositol was stimulated by equimolar oleate only twofold while that of phosphatidylethanolamine was $50 \%$ inhibited.

Sodium dodecylsulphate added at a level of $0.5 \mu \mathrm{mol} / \mu \mathrm{mol}$ phosphatidylcholine substrate was a potent activator of phospholipid breakdown (8- to I0-fold): higher concentrations caused an inhibition of the activity. With a detergent: substrate molar ratio of 5 , negligible activity was observed. 


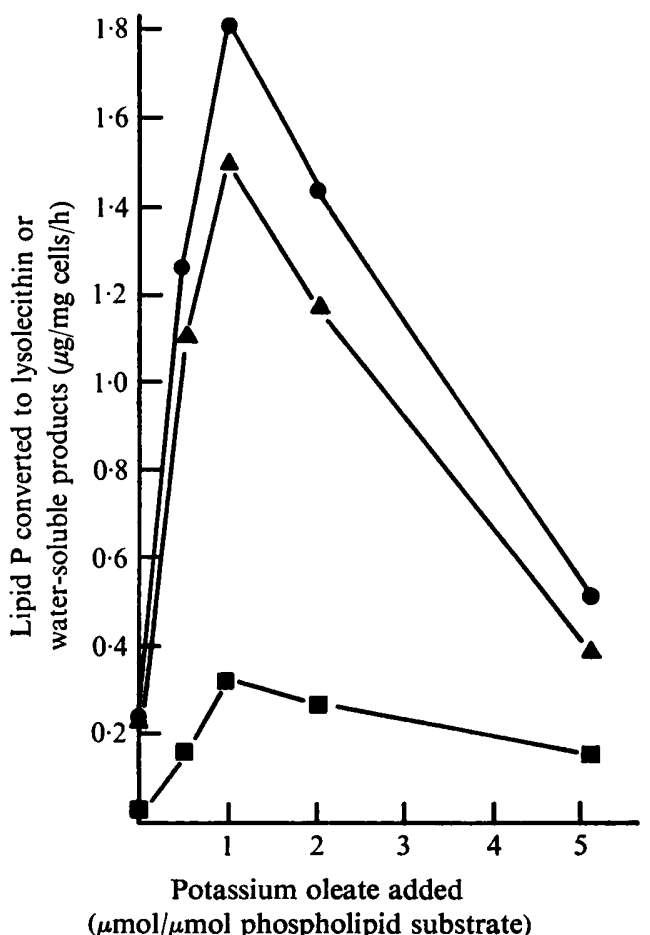

Fig. 2

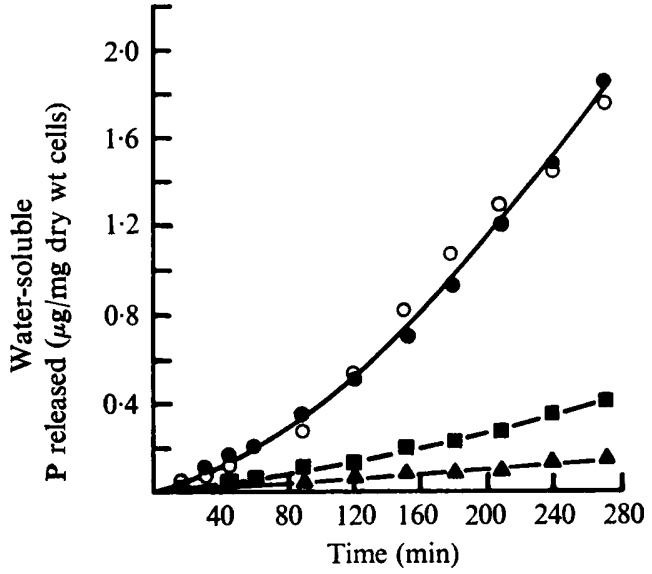

Fig. 3

Fig. 2. Effect of varying concentrations of potassium oleate on phospholipase activity. For each incubation, cells from $10 \mathrm{ml}$ portions of culture $(5.7 \mathrm{mg}$ dry wt cells) were harvested by centrifugation $4.25 \mathrm{~h}$ after maximum culture turbidity and washed once with o. I M-Na $\mathrm{NPO}_{4}-\mathrm{NaH}_{2} \mathrm{PO}_{4}$ buffer $\mathrm{pH} 6.8$ containing cysteine $\left(1 \mathrm{I}^{-1} \mathrm{M}\right)$ and EDTA $\left(1 \mathrm{O}^{-3} \mathrm{M}\right)$ before being resuspended to $4 \mathrm{ml}$ volume in the same buffer. After equilibration at $39^{\circ} \mathrm{C}$, the suspensions were transferred to tubes containing yeast [ ${ }^{32} \mathrm{P}$ ]phosphatidylcholine $(2 \mu \mathrm{mol})$ dispersed by vortexing for $30 \mathrm{~s}$ in I ml buffer to which had been added varying amounts of potassium oleate. Incubations were for $3 \mathrm{~h}$ at $39{ }^{\circ} \mathrm{C}$ under a gas phase of $\mathrm{O}_{2}$-free $\mathrm{CO}_{2}$. $\square$, Lysolecithin'released; $\boldsymbol{\Delta}$, water-soluble phosphorus released; , lysolecithin + water-soluble phosphorus.

Fig. 3. Effect of cysteine and oxygen on phospholipase activity. For each time-course study, cells from $20 \mathrm{ml}$ culture ( $17 \mathrm{mg}$ dry $\mathrm{wt}$ cells) were harvested by centrifugation $4 \mathrm{~h}$ after maximum culture turbidity, and washed once in the appropriate buffer plus the additions described below before being resuspended to $16 \mathrm{ml}$ volume in the same buffer. After equilibration at $39{ }^{\circ} \mathrm{C}$, cell suspensions were transferred to tubes containing yeast $\left[{ }^{32} \mathrm{P}\right]$ phosphatidylcholine $(240 \mu \mathrm{g} \mathrm{P})$ which had been dispersed in $4 \mathrm{ml}$ of $0.1 \mathrm{M}$-dimethylglutaric acid buffer $\mathrm{pH} 6.8$ with $10^{-3} \mathrm{M}$-EDTA and cysteine added as indicated. Incubations were carried out at $39^{\circ} \mathrm{C}$ with the indicated gas passing through continuously. Samples ( $1 \mathrm{ml}$ ) were withdrawn and treated with 20 volumes of chloroformmethanol $(2: \mathrm{I}, \mathrm{v} / \mathrm{v}) . \Delta$, Air and cysteine $\left(10^{-2} \mathrm{M}\right) ; \boldsymbol{\square}, \mathrm{O}_{2}$-free $\mathrm{N}_{2} ; \boldsymbol{O}, \mathrm{O}_{2}$-free $\mathrm{N}_{2}$ and cysteine $\left(\mathrm{IO}^{-2} \mathrm{M}\right) ; \mathrm{O}, \mathrm{CO}_{2}-\mathrm{N}_{2}(\mathrm{I}: 19, \mathrm{v} / \mathrm{v})$ and cysteine $\left(\mathrm{IO}^{-2} \mathrm{M}\right)$.

\section{Effect of other possible co-factors}

Calcium, which is an activator for many types of phospholipase activity, did not stimulate the hydrolysis of phosphatidylcholine when added at a concentration of $10^{-3} \mathrm{M}$. The same result was found with $1 \mathrm{O}^{-3} \mathrm{M}$-ferrous chloride. Cysteine at a concentration of $1 \mathrm{O}^{-2} \mathrm{M}$ produced an appreciable stimulation of activity (Fig. 3). During a $2 \mathrm{~h}$ incubation, the stimulated rate of hydrolysis was not affected by varying the added cysteine concentration over the range $5 \times 10^{-1}$ to $\mathrm{I} \times 10^{-4} \mathrm{M}$. The hydrolysis of phosphatidylcholine was very slow if a stream 

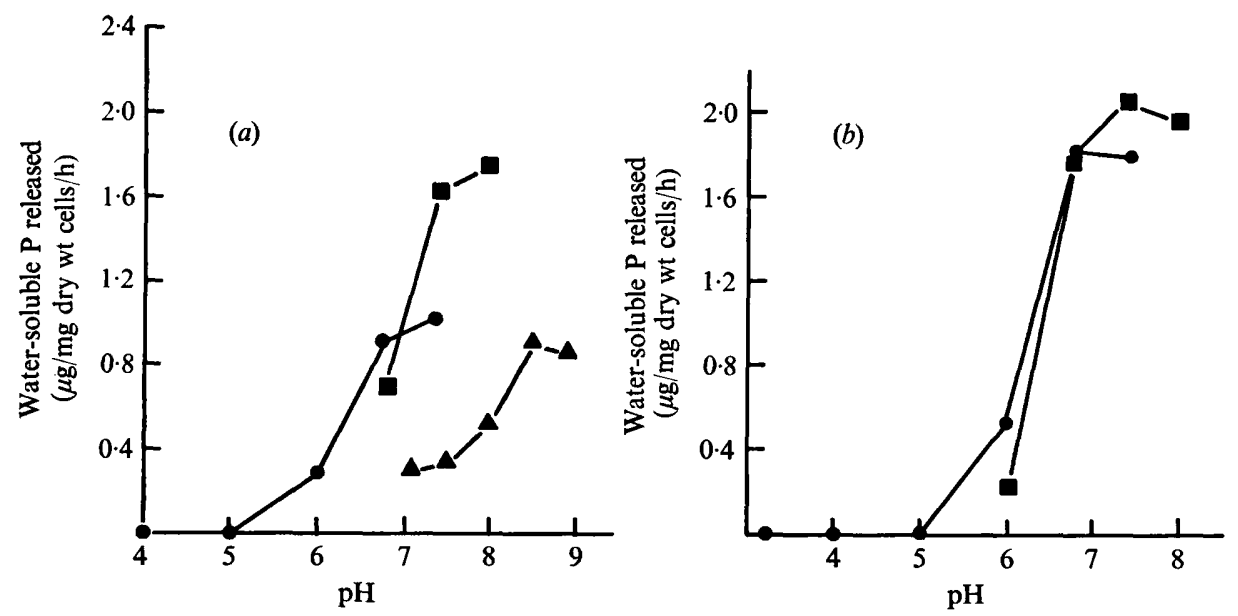

Fig. 4. Effect of pH on activity towards (a) phosphatidylcholine and $(b)$ phosphatidylethanolamine. For each incubation, cells from $10 \mathrm{ml}$ portions of culture $(7.1 \mathrm{mg}$ dry wt cells for incubations in dimethylglutaric acid buffer and $8.8 \mathrm{mg}$ dry wt cells for incubations in tris and phosphate buffers) were harvested by centrifugation $4.5 \mathrm{~h}$ after reaching maximum culture turbidity and were washed once with the appropriate buffer which contained cysteine $\left(2 \times 10^{-2} \mathrm{M}\right)$ and EDTA $\left(\mathrm{IO}^{-3} \mathrm{M}\right)$ before being resuspended to $4 \mathrm{ml}$ volume in the same buffer. After equilibration at $39{ }^{\circ} \mathrm{C}$, the cells were transferred to tubes containing either [ $\left.{ }^{32} \mathrm{P}\right]$ phosphatidylcholine ( $\left.{ }^{\circ} 05 \mu \mathrm{mol}\right)$ plus sodium dodecylsulphate $(\mathrm{I} \cdot 0 \mu \mathrm{mol})$ or $\left[{ }^{32} \mathrm{P}\right]$ phosphatidylethanolamine $(0.97 \mu \mathrm{mol})$ alone, and dispersed in $\mathrm{I} \mathrm{mI}$ buffer by vortexing for $30 \mathrm{~s}$ with a glass bead. Incubations were carried out at $39{ }^{\circ} \mathrm{C}$ for $1.5 \mathrm{~h}$ under a gas phase of $\mathrm{O}_{2}$-free $\mathrm{CO}_{2}$. $\mathrm{O}, \mathrm{O} \cdot \mathrm{I} \mathrm{M}-\mathrm{NaOH}$-dimethylglutaric acid buffers; $\mathbf{Q}, \mathrm{O} \cdot \mathrm{I} \mathrm{M}^{-} \mathrm{Na}_{2} \mathrm{HPO}_{4}-$ $\mathrm{NaH}_{2} \mathrm{PO}_{4}$ buffers; $\triangle$, O.I M-tris-HCl buffers.

of air rather than $\mathrm{N}_{2}$ or $\mathrm{CO}_{2}-\mathrm{N}_{2}(\mathrm{I}: 19, \mathrm{v} / \mathrm{v})$ was passed through the incubation medium, even though cysteine was present (Fig. 3). The hydrolysis stimulated by $\mathrm{IO}^{-2} \mathrm{M}$-cysteine was not inhibited by the addition of $1 \mathrm{O}^{-3} \mathrm{M}$-EDTA, again suggesting that divalent metal ions are not an essential component of the system.

\section{Effect of $p H$}

The hydrolysis of phosphatidylcholine in a series of buffers of differing $\mathrm{pH}$ seemed to vary not only with the pH but also with the buffer composition (Fig. 4). Activity appeared to be maximal at a $\mathrm{pH}$ above 8 but since the hydrolysis had been stimulated by the addition of sodium dodecylsulphate in these experiments, it is possible that the true optimum was somewhat lower. Quarles \& Dawson (1969) found that although sodium dodecylsulphate stimulated phospholipase $\mathrm{D}$, the $\mathrm{pH}$ optimum was shifted $\mathrm{I} \cdot 5 \mathrm{pH}$ units higher than in the non-stimulated hydrolysis. The non-stimulated hydrolysis of phosphatidylcholine proved to be too slow for a determination of the optimum to be undertaken. However, using phosphatidylethanolamine as substrate, where no activation was required, the $\mathrm{pH}$ optimum appeared to be in the region of 6.5 to 7.5 (Fig. 4), a $\mathrm{pH}$ similar to that in the rumen.

\section{Identification of $\mathrm{LM} 8 / \mathrm{IB}$}

The organism was an anaerobic Gram-negative, capsulated rod (I to $2 \times 0.5 \mu \mathrm{m}$ ). Motility was not obvious under shake-flask batch culture conditions, but was consistently present in young cultures grown statically in a liquid medium containing $0.05 \%(w / v)$ glucose as the only fermentable sugar, and was shown by electron microscopy to be by virtue of a single 
polar flagellum. In exponential-phase, shake-flask cultures individual cells were predominantly straight with rounded ends and tended to form filaments of three or more cells, but in stationary-phase batch cultures there were no filaments and the majority of individual cells had a pronounced curvature. The isolate was not capable of using cysteine, polypeptides or water-soluble material from autolysed yeast as its sole sources of fermentable carbon since it did not grow in the basal medium, but it grew vigorously in the presence of 20 out of a total of 26 different carbohydrates. Cellulose was not digested. The principal fermentation products were butyric acid, ethanol and hydrogen. When the organism was cultured in liquid medium (Hobson, I969; medium 2) containing rumen fluid and $0.5 \%(\mathrm{w} / \mathrm{v})$ glucose, butyric acid levels increased 6 to Io times that in uninoculated medium, and up to $25 \%$ of the acetic acid present in the medium was utilized. In liquid medium 2 containing $0.5 \%$ $(w / v)$ glucose but no rumen fluid, the isolate grew less vigorously but produced similar levels of butyric acid and about half as much acetic acid, on a molar concentration basis. There was no evidence of any absolute nutritional requirement for substances contained in rumen fluid, but growth was noticeably more vigorous in the presence of the fluid or a mixture of volatile fatty acids at concentrations similar to those in the rumen fluid. The results obtained for various identification tests were compared with the characteristics of known rumen bacterial genera as listed by Bryant (1959, 1963) and Hungate (1966). The isolate was similar to Butyrivibrio fibrisolvens with respect to 40 characteristics. As a consequence it was tentatively identified as a non-cellulolytic strain of $B$. fibrisolvens.

\section{DISCUSSION}

We obtained no evidence that the ability to degrade exogenous phospholipids rapidly is a widespread property among differing species of rumen bacteria. Although more than 200 isolations were made from the rumen contents of both normal and defaunated sheep on different feeding regimes, screening of these isolates for the ability to degrade added yeast $\left[{ }^{32} \mathrm{P}\right]$-lecithin under batch culture conditions revealed that only three isolates were really active in this respect. This paper has been concerned with only one of these isolates, but preliminary tests indicated that all three are similar, if not identical. This is in conformity with the limited distribution of rumen bacterial species which can hydrolyse triglycerides (Hobson \& Mann, I96I) and hydrogenate unsaturated fatty acids (Dawson \& Kemp, $1969 b$ ). The organism contained a phospholipase active against both phosphatidylcholine and phosphatidylethanolamine, the main phospholipids present in the herbage diet of a ruminant (Roughan \& Batt, 1969), and had properties which allowed it tentatively to be identified as a strain of Butyrivibrio fibrisolvens, a bacterium which commonly occurs in both ovine and bovine rumens. The property of degrading phospholipids appears not to be characteristic of all rumen Butyrivibrio species since other isolates (donated by $\mathrm{Mr} R$. W. White and Dr P. N. Hobson) were completely inactive. A decision as to the usual numbers of the present bacterium in the rumen and its importance in rumen metabolism must depend on further work.

The phospholipase A activity present in the organism produces a deacylation of the phospholipid substrate, initially liberating a lysophospholipid and a free fatty acid. The rapid appearance of a water-soluble glycerylphosphorylated derivative and minimal accumulation of lysophospholipid implies that an active lysophospholipase is also present. Phospholipase A associated with a dominant lysophospholipase has been frequently described in the membranes of other bacteria, e.g. Mycobacterium phlei (Ono \& Nojima, 1969). Serratia plymuthicum (Hayaishi \& Kornberg, 1954) and Escherichia coli (Proulx \& Van Deenen, 
1967; Shibuya \& Maruo, 197I). We could not determine whether the present phospholipase $A$ is specific for the fatty acid at the $I$ or 2 glycerol carbons of the phosphoglyceride molecule, because of the minimal appearance of lysophospholipid and the difficulty in separating phospholipase A from lysophospholipase activity due to the instability of the enzyme preparation. Sometimes both phospholipases $\left(A_{1}\right.$ and $\left.A_{2}\right)$ can be present in the same organism, although it is not certain whether two enzymes or a single enzyme lacking in specificity is involved (Doi \& Nojima, 1973).

The present phospholipase activity shows a number of characteristics which are unusual when compared with bacterial deacylating systems previously studied. The marked activation caused by cysteine is exceptional and is possibly connected with the necessity of providing a low redox potential to prevent oxygen poisoning of the enzymes. Little enzymic activity was observed when the incubation with substrate was carried out under aerobic conditions. A slight activation of a lysolecithin deacylating enzyme in Vibrio cholera by glutathione and cysteine has been reported (Chattergee \& Mitra, 1962) but the present effect is of an entirely different magnitude.

Most types of bacterial phospholipase A previously studied had an absolute requirement for $\mathrm{Ca}^{2+}$ ions. However, the present enzyme is not stimulated by addition of this divalent cation or inhibited by the addition of EDTA. In this respect it is similar to the soluble enzyme produced by Bacillus megaterium (Raybin, Bertsch \& Kornberg, 1972). The latter enzyme is also similar to the present system in that it is greatly stimulated by the presence of anionic detergents when it is attacking a zwitterionic phospholipid. It therefore seems likely that the present enzyme system prefers a substrate-water interface which contains an excess of negative charges. This would also explain the stimulatory effect of oleic acid which is likely to enter the substrate particles and present orientated and ionized carboxylic acid groups at the interface. The lack of stimulatory action of oleic acid using a phosphatidylethanolamine substrate could possibly be due to the surface of the phosphatidylethanolamine particles already having a negative charge at a neutral $\mathrm{pH}$ due to deprotonization of some of the amino groups (Dawson, 1963). [Many phospholipid-metabolizing enzymes have a very precise requirement for the Zeta potential appertaining on the surface of the substrate (Dawson, 1973).

Few attempts have been made previously to equate phospholipase activity with the stage of bacterial growth, although Chattergee \& Mitra (1962) found that the lysolecithinase of $V$. cholera appeared in the late exponential phase and was maintained through $30 \mathrm{~h}$ of stationary phase. The development of the present enzyme in shake-flask batch cultures appears to be specifically associated with autolysis of the organism, as shown by the decrease in the turbidity of the culture and by electron microscopy. The association of enzymic activity with a comparatively short phase of the growth of the organism does not preclude it playing a physiological role in degrading dietary phospholipid in a rumen environment. Hobson (1970) has indicated that the death and lysis of rumen bacterial cells, which frequently follows the cessation of rapid growth in batch cultures in vitro, almost certainly occurs in vivo also. In a similar context, Jarvis (1968) found that Streptococcus bovis and a species of Butyrivibrio were susceptible to lysis when placed in rumen contents, so it would seem that lysis could result in the unmasking of phospholipase activity in vivo.

Although both the intact cells and the soluble enzyme can degrade phospholipids, it is possible that the latter rapidly disappears in the rumen because active proteolytic enzymes are known to degrade certain soluble proteins added to the rumen (Mangan, 1972). A number of experiments in the present investigation have shown that ovine rumen fluid centrifuged to remove all bacteria is virtually devoid of phospholipase activity. However, 
even with a short half-life the soluble enzyme could still be physiologically active. The hydrolysis of dietary triglycerides in the rumen may, in part at least, be brought about by an extracellular lipase secreted by Anaerovibrio lipolytica (Henderson, 1971), yet rumen fluid supernatant seems to be totally devoid of the enzyme (Garton, Lough \& Vioque, 196I).

One of the authors (G.P.H.) thanks Dr P. N. Hobson for initial instruction in handling rumen anaerobic bacteria during a visit to his laboratory; Miss N. Hemington is thanked for preparing the labelled phospholipid substrates.

\section{REFERENCES}

Abou Akkada, A. R., Bartley, E. E., Berube, R., Fina, L. R., Meyer, R. M., Henricks, D. \& Julius, F. (1968). Simple method to remove completely ciliate protozoa of adult ruminants. Applied Microbiology I6, $1475-1477$.

Bangham, A. D. \& Dawson, R. M. C. (1959). The relation between the activity of a lecithinase and the electrophoretic charge of the substrate. Biochemical Journal 72, 486-492.

Bangham, A. D. \& Dawson, R. M. C. (1960). The physiochemical requirements for the action of Penicillium notatum phospholipase $\mathrm{B}$ on unimolecular films of lecithin. Biochemical Journal 75, 133-138.

Bartlett, G. T. (1959). Phosphorus assay in column chromatography. Journal of Biological Chemistry 234 , 466-47I.

Bryant, M. P. (1959). Bacterial species of the rumen. Bacteriological Reviews 23, I25-I 53.

BRYANT, M. P. (1963). Symposium on microbial digestion in ruminants: identification of groups of anaerobic bacteria active in the rumen. Journal of Animal Science 22, 801-813.

Caldwell, D. R. \& BRYANT, M. P. (I966). Medium without rumen fluid for non-selective enumeration and isolation of rumen bacteria. Applied Microbiology 14, 794-80I.

Chattergee, G. C. \& Mitra, S. (1962). Studies on phospholipid-splitting enzyme of Vibrio el Tor. Biochemical Journal 83, 384-387.

Coleman, G. S., Kemp, P. \& Dawson, R. M. C. (I97I). The catabolism of phosphatidylethanolamine by the rumen protozoon Entodinium caudatum and its conversion into the $N$-(I-carboxyethyl) derivative. Biochemical Journal 123, 97-104.

Dawson, R. M. C. (1956). Studies on the phosphorylcholine of rat liver. Biochemical Journal 62, 693-696.

Dawson, R. M. C. (1959). Hydrolysis of lecithin and lysolecithin by rumen micro-organisms of the sheep. Nature, Lond. $183,1822-1823$.

Dawson, R. M. C. (1963). On the mechanism of action of phospholipase A. Biochemical Journal 88, 414-423.

Dawson, R. M. C. (I973). Specificity of enzymes involved in the metabolism of phospholipids. In Form and Function of Phospholipids, vol. 3, pp. 97-I I6. Edited by G. B. Ansell, J. N. Hawthorne and R. M. C. Dawson. London: Elsevier.

Dawson, R. M. C. \& HAuser, H. (1967). On the mechanism of the stimulation by anionic amphipaths of lecithin hydrolysis by phospholipase B of Penicillium notatum. Biochimica et biophysica acta 137, 518-524.

Dawson, R. M. C. \& Hemington, N. (1974a). Digestion of grass lipids and pigments in sheep rumen. British Journal of Nutrition 32, 327-340.

Dawson, R. M. C. \& Hemington, N. (1974b). An inhibitor of phospholipase D in saliva. Biochemical Journal 143, 247-430.

Dawson, R. M. C. \& KeMP, P. (1969a). The effect of defaunation on the phospholipids and on the hydrogenation of unsaturated fatty acids in the rumen. Biochemical Journal $115,35 \mathrm{I}-352$.

Dawson, R. M. C. \& KEMP, P. (1969b). Biohydrogenation of dietary fats in ruminants. In Physiology of Digestion and Metabolism in the Ruminant, pp. 504-518. Edited by A. T. Phillipson. Newcastle-uponTyne: Oriel Press Ltd.

Dor, O. \& Nojima, S. (1973). Detergent-resistant phospholipase $\mathrm{A}_{1}$ and $\mathrm{A}_{2}$ in Escherichia coli. Journal of Biochemistry 71, 667-674.

EPSTEIN, B. \& SHAPIRo, B. (1959). Lecithinase and lysolecithinase of intestinal mucosa. Biochemical Journal 7I, 6I5-6I9.

Faruque, A. J. M. O., Jarvis, B. D. W. \& Hawke, J. C. (I974). Contribution of plant lipases to the release of free fatty acids in the rumen. Journal of the Science of Food and Agriculture 25, 1313-I 328. 
Garton, G. A., Lough, A. K. \& VIOQUE, E. (r96I). Glyceride hydrolysis and glycerol fermentation by sheep rumen contents. Journal of General Microbiology 25, 215-225.

HAUSER, H. \& Dawson, R. M. C. (1967). Stability of unimolecular films of ${ }^{32}$ P-labelled lecithin. Biochemical Journal ro5, 40I-407.

HAYAISH, O. \& KORNBERG, A. (1954). Metabolism of phospholipids by bacterial enzymes. Journal of Biological Chemistry 206, 647-663.

HeNDERSON, C. (1971). A study of the lipase produced by Anaerovibrio lipolytica, a rumen bacterium. Journal of General Microbiology 65, 8I-89.

Hobson, P. N. (1969). Rumen bacteria. In Methods in Microbiology, vol. 3B, pp. 133-149. Edited by J. R. Norris and D. W. Ribbons. London and New York: Academic Press.

Hobson, P. N. (1970). Rumen micro-organisms. Progress in Industrial Microbiology 9, 41-77.

Hobson, P. N. \& MANN, S. O. (1961). The isolation of glycerol-fermenting and lipolytic bacteria from the rumen of the sheep. Journal of General Microbiology 25, 227-240.

Hobson, P. N. \& MANN, S. O. (1971). Isolation of cellulolytic and lipolytic organisms from the rumen. In Isolation of Anaerobes, Society of Applied Bacteriology, Technical Series 5, pp. 149-158. Edited by D. A. Shapton and R. G. Board. London: Academic Press.

Hungate, R. E. (1966). The rumen bacteria. In The Rumen and its Microbes, pp. 8-90. New York and London: Academic Press.

Hungate, R. E. (1969). A roll tube method for cultivation of strict anaerobes. In Methods in Microbiology, vol. 3B, pp. I1 1-132. Edited by J. R. Norris and D. W. Ribbons. New York and London: Academic Press.

JARVIS, B. D. W. (1968). Lysis of viable rumen bacteria in bovine rumen fluid. Applied Microbiology 16, 714-723.

LANCHLI, A. (1969). Radioassay for $\beta$-emitters in biological materials using Cerenkov radiation. International Journal of Applied Radiation and Isotopes 20, 265-270.

LATHAM, M. J. \& ShARpe, E. M. (I97I). The isolation of anaerobic organisms from the bovine rumen. In Isolation of Anaerobes, Society of Applied Bacteriology, Technical Series 5, pp. 133-147. Edited by D. A. Shapton and R. G. Board. London and New York: Academic Press.

MANGAN, J. L. (1972). Quantitative studies on nitrogen metabolism in the bovine rumen, the rate of proteolysis of casein and ovalbumin and the release and metabolism of amino acids. British Journal of Nutrition 27, 26I-283.

ONo, Y. \& NoJimA, S. (1969). Phospholipase A of Mycobacterium phlei: a regulatory membrane enzyme with ferric ion as effector. Journal of Biochemistry 65, 979-981.

Proulx, P. R. \& Van Deenen, L. L. M. (1967). Phospholipase activities of Escherichia coli. Biochimica et biophysica acta 144, $17 \mathrm{I}-174$.

QuarLes, R. H. \& Dawson, R. M. C. (1969). A shift in the optimum pH of phospholipase D produced by activating long-chain anions. Biochemical Journal 112, 795-799.

RAYBIN, D. M., BeRTSCH, L. L. \& KorNBERG, A. (1972). A phospholipase in Bacillus megaterium unique to spores and sporangia. Biochemistry II, I 754-1 760 .

Roughan, P. G. \& Batt, R. D. (1969). The glycerolipid composition of leaves. Phytochemistry 8, 363-369.

Sheltawy, A. \& Dawson, R. M. C. (1969). Separation and estimation of phospholipids. In Chromatographic and Electrophoretic Techniques, 2nd edn., vol. I, pp. 450-493. Edited by I. Smith. London: William Heinemann, Pitman Medical.

Shibuya, I. \& Maruo, B. (1971). Phospholipases of Escherichia coli. I. Lipoprotein phospholipase A. Agricultural and Biological Chemistry 35, $1180-1187$.

Subbaiah, P. V. \& GaNGULY, J. (1970). Studies on the phospholipases of rat intestinal mucosa. Biochemical Journal 118, 233-239.

VASKovsky, V. E. \& Kostetsky, E. Y. (I968). Modified spray for detection of phospholipids on thin-layer chromatograms. Journal of Lipid Research 9, 396-397.

Waite, M., Scherphof, G. L., Boshouwers, F. M. G. \& Van Deenen, L. L. M. (1969). Differentiation of phospholipases A in mitochondria and lysosomes of rat liver. Journal of Lipid Research 1o, 41 1-420. 